\title{
IN VITRO CYTOTOXIC ACTIVITY OF NIGELLA SATIVA L. ON HUMAN MALIGNANT MELANOMA CELL LINES
}

\author{
NIZAMI DURAN ${ }^{1}$, GULAY GULBOL DURAN ${ }^{2}$, EMRAH AY $^{1}$, DURMUŞ ALPASLAN \\ KAYA $^{3}$, MADALINA GEORGIANA ALBU KAYA ${ }^{4}$, AHMET MERT ${ }^{3}$ \\ ${ }^{1}$ Mustafa Kemal University, Medical Faculty, Department of Microbiology \& Clinical \\ Microbiology, Hatay-Turkey, nizamduran@hotmail.com \\ ${ }^{2}$ Mustafa Kemal University, Medical Faculty, Department of Medical Biology\&Genetics, Hatay- \\ Turkey,gulaygulbol@gmail.com \\ ${ }^{3}$ Mustafa Kemal University, Faculty of Agriculture, Department of Field Crops, Hatay-Turkey, \\ dak1976@msn.com \\ ${ }^{4}$ INCDTP -Division Leather and Footwear Research Institute (ICPI), 93 Ion Minulescu St., \\ 031215, Bucharest, Romania, albu_mada@yahoo.com
}

\begin{abstract}
Nigella is a medicinal plant that has various pharmacological properties. It is widely used in folk medicine to treat many diseases in the world. It was aimed to investigate the essential oils Nigella sativa $\mathrm{L}$. on two human melanoma cells (A-375 and A-2058 cell lines). In this study, two different cancer cell lines (A375 and A-2058 cell lines) and one normal cell culture (vero cells) were used. Firstly, the non-toxic concentrations the essential oils of Nigella sativa L. were determined on normal cells (Vero cell line). And then, the cytotoxicity test were applied at these non-toxic concentrations. The cytotoxic activity of the essential oils of Nigella sativa L. on the cell lines was measured by MTT and Trypan blue assays. The chemical components analyses of the Nigella sativa L. oils were carried out by GC-MS. Medically important various components of Nigella sativa $\mathrm{L}$. were determined in the GC-MS analysis. Some of these components are as follows; anethole (22.97\%), thymoquinone (21.36\%), $\alpha$-thujene (6.22\%), longifolene (5.76\%), trans-isoeugenol (3.55\%), carvacrol (2.23\%). A total of 24 compounds were identified. The essential oils of Nigella sativa L. were found to inhibit the cell proliferation of human malignant melanoma cells. The IC50 values of the essential oils of Nigella sativa L. It were investigated as compared with a standard drug (methotrexate). Statistically significant decrease on the cell proliferations was found in the cells treated with the essential oils of Nigella sativa $\mathrm{L}$. It was found to be non-toxic on normal cells (on Vero cell line) at the effective concentrations of the essential oils. While the non-toxic concentrations of essential oils on Vero cell line were found to be $12.5 \mu \mathrm{g} / \mathrm{ml}$, the effective concentrations for A-375 and A-2058 cell lines were as $1.56 \mu \mathrm{g} / \mathrm{ml}$ and $3.12 \mu \mathrm{g} / \mathrm{ml}$, respectively. In conclusion, the essential oils of Nigella sativa L. were found to be significantly inhibited the cell proliferation on the human melanoma cells. The effect may arise from the components situated in the structure of Nigella sativa L. such asanethole, thymoquinone, $\alpha$ thujene, longifolene, trans-isoeugenol and carvacrol. These components of this plant have been found promising in the treatment for human melanomas. But further studies, especially further animal studies should be needed to explain the action mechanisms of these components.
\end{abstract}

Keywords: A-375 cell line, A-2058 cell line, melanoma, cytotoxicity, proliferation, MTT.

\section{INTRODUCTION}

Turkey has a rich flora in terms of medicinal plants. There is plenty of endemic plant species especially in the Hatay region located in the south of Turkey. Nigella is a useful plant that naturally grown or cultured in Hatay commonly used in the treatment of various diseases. The seeds of Nigella sativa $L$. have been reported to use in the treatment of many different diseases and disorders. In Islamic literature, it is considered as one of the major herbal medicine (Ali and Blunden, 2003).

In folk medicine, Nigella oil has been widely used to treat many diseases such as peritonitis, cough, bronchitis, oedama, headache, rheumatism, fever, influenza and eczema for centuries in many countries (Burits and Bucar, 2003).

Some studies were carried out about the anti-carcinogenic effects of Nigella spp., although the number of studies on human malignant melanoma is quite limited (Alenzi et al., 2010; Alhebshi et al., 2013; El-Mahdy et al., 2005; Ulasli et al., 2013; Woo et al., 2011). 
Even, we did not find any studies that investigate the effectiveness of Nigella sativa L. against human melonoma cells. Melanoma is a skin malignant tumor that occurred as a result of the melanocyte transformation and one of the important cancer types for human health. Studies indicated that melanoma begin to appear more often than the other cancer types all over the world (Sun and Schuchter, 2001).

The incidence of melanoma has been reported to increase day by day. As in other cancers, there is no powerful drug choice for pharmacological treatment in melanoma chemotherapy. In addition to this, the drugs used in the treatment of human malignant melanoma have been reported to show high toxicity and low effectiveness. Hence, new drug research for the treatment of melanoma continues rapidly (Atallah and Flaherty, 2005; Goldberg et al., 2007).

In this study, we aimed to investigate in-vitro cytotoxic and antiproliferative activities of Nigella sativa L. on two human malignant melanoma (A-375 and A-2058 cell lines) cells compared to normal cells (Vero cell line).

\section{MATERIALS AND METHODS}

\section{Isolation of the Essential Oil}

Black Cumin (Nigella sativa L.) seeds were obtained from the spice bazaar of Antakya. Essential oils were obtained from seeds after powdered. The seeds of black cumin (100 g) were extracted by hydrodistillation with $1 \mathrm{~L}$ distilled water for $3 \mathrm{~h}$ using Neo-Clevenger apparatus. The oils were dried over anhydrous sodium sulfate and then stored in dark color glass bottles, at $-4{ }^{\circ} \mathrm{C}$ ready for GC-MS analysis.

\section{Analysis of GC/MS}

Analysis of the essential oils carried out by using Thermo Scientific Focus Gas Chromatograph equipped with MS, auto sampler and TR-5MS (5\% Phenyl Polysilphenylenesiloxane, $0.25 \mathrm{~mm}$ x $30 \mathrm{~m}$ i.d, film thickness 0.25 ). The carrier gas was helium $(99.9 \%$ ) at a flow rate of $1 \mathrm{~mL} / \mathrm{min}$; ionization energy was $70 \mathrm{eV}$. Mass range $\mathrm{m} / \mathrm{z}$ 50-650 amu. Data acquisition was scan mode. MS transfer line temperature was $250{ }^{\circ} \mathrm{C}$, MS Ionization source temperature was $220^{\circ} \mathrm{C}$, the injection port temperature was $220^{\circ} \mathrm{C}$. The samples were injected with 250 split ratio. The injection volume was $1 \mathrm{~L}$. Oven temperature was programmed in the range of 50 to $220{ }^{\circ} \mathrm{C}$ at $3{ }^{\circ} \mathrm{C} / \mathrm{min}$. The structure of each compound was identified by comparison with their mass spectrum (Wiley9 library). The data were handled using Xcalibur software program. The retention indices (RIs) were calculated for all volatile constituents using a homologous series of n-alkane standard solutions $\mathrm{C}_{8}-\mathrm{C}_{20}$ (Fluka, product no. 04070) and $\mathrm{C}_{21}-\mathrm{C}_{40}$ (Fluka, product no. 04071).

Table 1. Essential oil components Nigella sativa L.

\begin{tabular}{ccccc}
\hline RT & RI & Compound Name & Cas \# & Area \% \\
\hline 3,48 & 1016 & $\alpha$-Thujene & $2867-05-2$ & 6,22 \\
3,65 & 1029 & $\alpha$-Pinene & $80-56-8$ & 3,71 \\
4,06 & 1056 & Camphene & $79-92-5$ & 0,93 \\
5,06 & 1107 & Sabinene & $3387-41-5$ & 1,83 \\
5,19 & 1114 & $\beta$-Pinene & $127-91-3$ & 1,46 \\
6,56 & 1172 & $\beta$-Myrcene & $123-35-3$ & 0,43 \\
6,88 & 1183 & Limonene & $138-86-3$ & 4,55 \\
7,06 & 1189 & Eucalyptol & $470-82-6$ & 0,74 \\
\hline
\end{tabular}


ICAMS $2016-6^{\text {th }}$ International Conference on Advanced Materials and Systems

\begin{tabular}{ccccc}
\hline \hline RT & RI & Compound Name & Cas \# & Area \% \\
\hline 7,12 & 1191 & $\beta$-Phellandrene & $555-10-2$ & 0,13 \\
8,21 & 1230 & $\gamma$-Terpinene & $99-85-4$ & 0,44 \\
9,15 & 1260 & p-Cymene & $99-87-6$ & 17,16 \\
18,89 & 1524 & trans-Sabinene hydrate & $17699-16-0$ & 0,31 \\
19,36 & 1537 & Linalyl acetate & $115-95-7$ & 0,22 \\
19,94 & 1552 & Endobornyl acetate & $76-49-3$ & 0,96 \\
20,38 & 1563 & Caryophyllene & $87-44-5$ & 0,67 \\
20,89 & 1576 & Terpinen-4-ol & $562-74-3$ & 0,3 \\
25,38 & 1695 & $\beta$-Bisabolene & $495-61-4$ & 0,21 \\
29,03 & 1796 & Anethole & $4180-23-8$ & 22,97 \\
29,90 & 1822 & p-Cymenol & $1197-01-9$ & 0,86 \\
36,65 & 2023 & Thymoquinone & $490-91-5$ & 21,36 \\
40,09 & 2151 & trans-Isoeugenol & $5932-68-3$ & 3,55 \\
41,68 & 2215 & Carvacrol & $499-75-2$ & 2,23 \\
43,22 & 2255 & Longifolene & $475-20-7$ & 5,76 \\
44,65 & 2290 & Longifolenaldehyde & $19890-84-7$ & 1,39 \\
\hline \multicolumn{5}{c}{}
\end{tabular}

\section{Cell Culture Studies}

In the present study, as cancer cell cultures two different human malignant melanoma cell lines (A375 and A-2058 cell lines) and as a normal cell culture Vero cell line were selected. Human melanomas and Vero cell cultures were obtained Mustafa Kemal University, Virology laboratory's culture collections, Hatay, Turkey. The cells were cultured in RPMI-1640 medium, supplemented with 10\% (v/v) fetal bovine serum, L-glutamine and antibiotics (100 units/ml penicillin and $100 \mathrm{~g} / \mathrm{ml}$ streptomycin). The incubation of the cell cultures was performed at $37^{\circ} \mathrm{C}$ with $5 \% \mathrm{CO}_{2}$ in a humidified incubators.

\section{Effect of DMSO}

Dimethyl sulfoxide (DMSO) was selected as a solvent to solve the essential oils of Nigella sativa L. In order to test the effects of DMSO (Sigma, USA), $1 \times 10^{6}$ cells were inoculated into each well of micro plates containing RPMI-1640 medium (Gibco-BRL). And then, the cultures were incubated for 72 hours in the presence of decreasing amounts of DMSO $(4,2,1.5,1.0,0.8,0.4,0.2,0.1 \%)$. The non-toxic concentration was determined equals and lower than $2 \%$. In the experiments, the essential oils of Nigella sativa $\mathrm{L}$. were dissolved in $1 \%$ DMSO.

\section{Trypan Blue Exclusion}

The cell viabilities in the cultures, trypan blue dye assay method was used. For this dying, 1001 of Nigella sativa L.'s oils was mixed with 8001 of PBS (phosphate buffer saline) and 1001 cell suspension was added. Each concentration of the essential oils was performed in triplicate. Then, the prepared mixtures were incubated at $37^{\circ} \mathrm{C}$ in an incubator for $30 \mathrm{~min}$. Finally, 1001 of trypan blue dye was added to this mixture. The viability of the cells was determined in a haemocytometer by a light microscope (Gupta, 2002).

\section{MTT Test}

MTT assay was performed as previously described by Mossman (Mosmann, 1983). The Vero (normal cells), A375 (human melanoma) and A-2058 (human melanoma) cell lines were cultured in RPMI-1640 medium with $10 \%$ (w/v) fetal bovine serum. Incubation of the cells was performed above mentioned conditions. The culture cells inoculated in 96-well plates overnight. The plaques were assessed at the incubation of 
96 hours. The cells in the plaques were washed at least three times with PBS after incubation, and then, $100 \mathrm{~L}$ of $0.5 \mathrm{mg} / \mathrm{mL}$ MTT were added to all wells and incubated at $37{ }^{\circ} \mathrm{C}$. The plaques were incubated for 30 minutes at the same conditions. MTT reduction ratio was determined by measuring the difference in absorbance at $570 \mathrm{~nm}$ using a microplate reader. All tests were performed in triplicate.

\section{Statistical Analysis}

All measurements were expressed as mean \pm standard deviation. Statistical analyses of data were performed using Student t-test. The $p$ value $<0.05$ was considered significant. All data were obtained in the experiments repeated three times. For statistical evaluation, SPSS, a Windows based program was used to assess data.

\section{RESULTS AND DISCUSSION}

The chemical composition of the essential oils of Nigella sativa $\mathrm{L}$. is given in Table 1 . The chemical components analyses of the Nigella sativa $\mathrm{L}$. oils were carried out by GC-MS. A total of 24 compounds of Nigella sativa L.'s oils were identified. In the GC-MS analysis, Nigella sativa L. was found to have many medically important components. Some of these these valuable components and their percentages as follows; anethole (22.97\%), thymoquinone $(21.36 \%), \alpha$ thujene (6.22\%), longifolene (5.76\%), trans-isoeugenol (3.55\%), carvacrol (2.23\%). The essential oils of Nigella sativa $\mathrm{L}$. were found to inhibit the cell proliferation of human malignant melanoma cells. The $\mathrm{IC}_{50}$ values of the essential oils of Nigella sativa $\mathrm{L}$. were compared with a standard drug (Methotrexate).Statistically significant decrease on the cell proliferations was found in the cells treated with the essential oils of Nigella sativa $\mathrm{L}$. It was found to be non-toxic on Vero cell line at these effective concentrations of the essential oils.

In the present study, while the non-toxic concentrations of essential oils on Vero cell line were found to be $12.5 \mu \mathrm{g} / \mathrm{ml}$, the effective concentrations for A-375 and A-2058 cell lines were as $1.56 \mu \mathrm{g} / \mathrm{ml}$ and $3.12 \mu \mathrm{g} / \mathrm{ml}$, respectively (Figure 1).

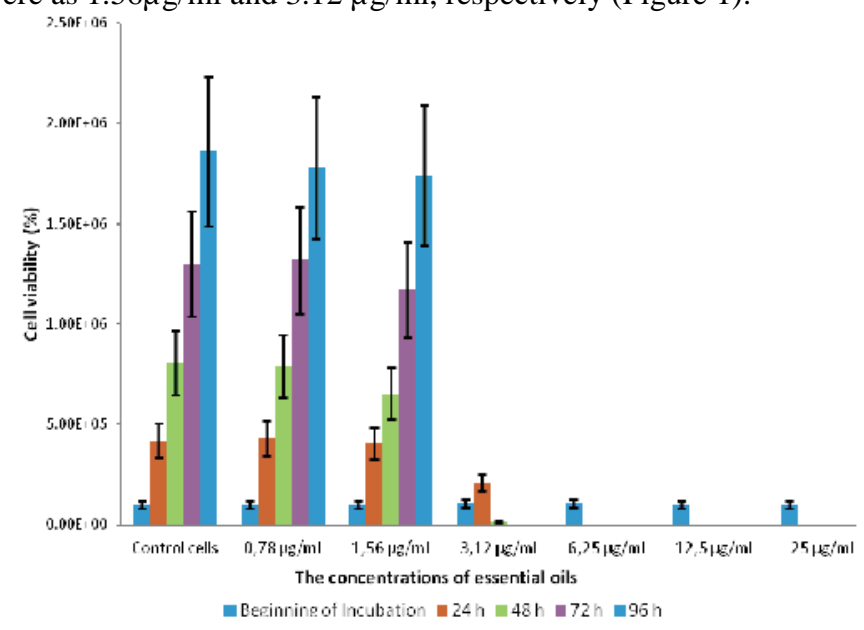

Figure 1. Cytotoxicity of the essential oils of Nigella sativa L. on A-375 cell line 
ICAMS $2016-6^{\text {th }}$ International Conference on Advanced Materials and Systems

When the essential oils of Nigella sativa L. compared to MTX, the efficacy of Nigella sativa L. found to be lower than MTX. But, cancer cell proliferation significantly inhibited by the essential oils of Nigella sativa L. (Figure 2).

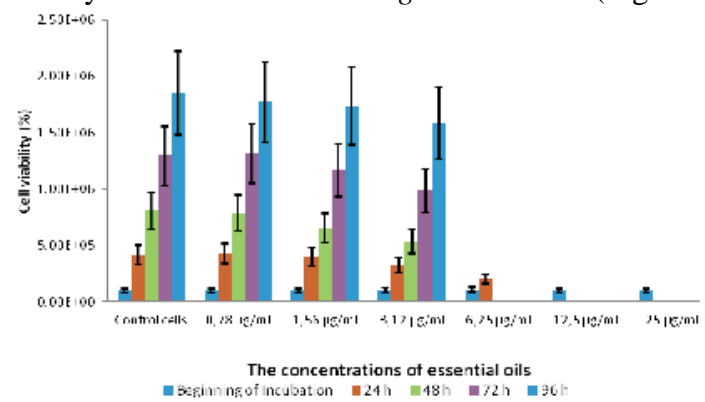

Figure 2. Cytotoxicity of the essential oils of Nigella sativa L. on A-2058 cell line

In the GC-MS analyses, anethole (22.97\%), thymoquinone (21.36\%), $\alpha$-thujene (6.22\%), longifolene $(5.76 \%)$, trans-isoeugenol $(3.55 \%)$, carvacrol $(2.23 \%)$ were identified as the major constituents of Nigella sativa L. The studies conducted previously in the literature reported that the phytochemical anethole possesses the anticancer activity against breast cancer cells (Muthukumari et al., 2013). Thymoquinone is one of the most common components of the Nigella sativa L. Similarly, thymoquinone has reported to have a significant anticancerogen agent for mouse colon carcinoma (MC38) cells (Agbaria et al., 2015). Before the studies, it's reported that carvacrol has an anti-proliferative and proapoptotic effects on human hepatocellular carcinoma cell line HepG-2 (Yin et al., 2012).

The components of Nigella sativa L. on various cancer cell lines were studied, though, we have not found any study that performed on human melanoma cells. As we know, this study is one of the first studies carried out on human melanoma cells in the south of Turkey.

Besides, in the experiment, the inhibition concentrations of the essential oils of Nigella sativa $\mathrm{L}$. against as cancer cell cultures in two different cell lines (A-375 and A-2058 cell lines) and a healthy cell line (Vero cell line) were evaluated. While the $\mathrm{IC}_{50}$ values of the essential oils of Nigella sativa L. against A-375 and A-2058 cell lines were determined as $1.56 \mu \mathrm{g} / \mathrm{ml}$ and $3.12 \mu \mathrm{g} / \mathrm{ml}$, respectively, this value for Vero cells was determined as $12.5 \mu \mathrm{g} / \mathrm{ml}$. Although, the $\mathrm{IC}_{50}$ values for MTX against A-375 and A-2058 cell lines were determined to be lower than Nigella sativa L., the essential oils of Nigella sativa L. were found to be highly active to inhibit the proliferation of melanoma cells (Figure 3).

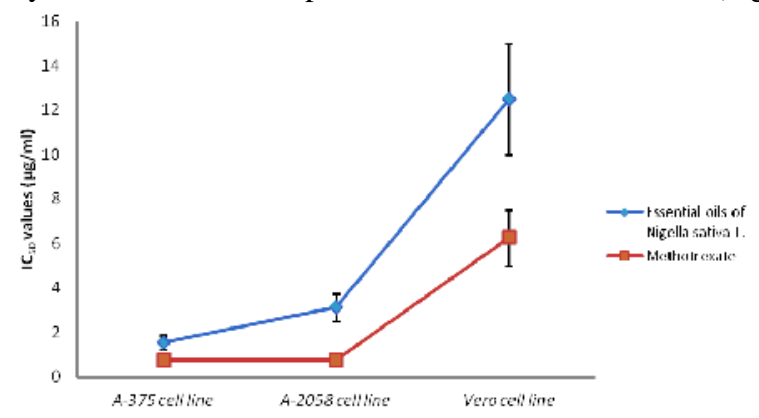

Figure 3. $\mathrm{IC}_{50}$ values of the essential oils of Nigella sativa $\mathrm{L}$. on three different cell lines 


\section{CONCLUSIONS}

In conclusion, the essential oils of Nigella sativa $\mathrm{L}$. were found to be significantly inhibited the cell proliferation on the human melanoma cell lines. The effect may arise from the components situated in the structure of Nigella sativa L. such as anethole, thymoquinone, $\alpha$-thujene, longifolene, trans-isoeugenol, carvacrol. The components of this plant have been found promising in the treatment of human melanoma. But further studies, especially further animal studies should be needed to explain the action mechanism of action. To explain the mechanism of the effect, additional studies are required.

\section{REFERENCES}

Agbaria, R., Gabarin, A., Dahan, A. and Ben-Shabat, S. (2015), “Anticancer activity of Nigella sativa (black seed) and its relationship with the thermal processing and quinone composition of the seed", Journal of Drug Design, Development and Therapy, 9, 3119-24.

Alenzi, F.Q., El-Bolkiny, Y. and Salem, M.L. (2010), "Protective effects of Nigella sativa oil and thymoquinone against toxicity induced by the anti -cancer drug cyclophosphamide", British Journal of Biomedical Science, 67, 20-28.

Alhebshi, A.H., Gotoh, M. and Suzuki, I. (2013), "Thymoquinone protects cultured rat primary neurons against amyloid beta-induced neurotoxicity", Biochemical and Biophysical Research Communications, 433, 362-7.

Ali, B.H. and Blunden, G. (2003), "Pharmacological and toxicological properties of Nigella sativa", Phytotherapy Research, 17, 299-305.

Atallah, E. and Flaherty, L. (2005), "Treatment of metastatic malignant melanoma", Current Treatment Options in Oncology, 6, 185-93.

Burits, M. and Bucar, F. (2000), "Antioxidant activity of Nigella sativa essential oil", Phytotherapy Research, $14,3238$.

El-Mahdy, M.A., Zhu, Q., Wang, Q.E. et al. (2005), "Thymoquinone induces apoptosis through activation of caspase-8 and mitochondrial events in p53-null myeloblastic leukemia HL-60 cells", International Journal of Cancer, 117, 409-17.

Goldberg, M.S., Doucette, J.T., Lim, H.W. et al. (2007), "Risk factors for presumptive melanoma in skin cancer screening: American Academy of Dermatology National Melanoma/Skin Cancer Screening Program experience 2001-2005", Journal of the American Academy of Dermatology, 57, 60-6.

Mosmann, T. (1983), "Rapid colorimetric assay for cellular growth and survivalapplication to proliferation and cytotoxicity assays", Journal of Immunological Methods, 65, 55-63.

Muthukumari, D., Padma, P.R. and Sumathi, S. (2013), "In Vitro Analysis of Anethole as an Anticancerous Agent for Triple Negative Breast Cancer", International Journal of Pharmaceutical Sciences Review and Research, 50, 314-8.

Sun, W. and Schuchter, L.M. (2001), "Metastatic melanoma", Current Treatment Options in Oncology, 2, $193-202$.

Ulasli, S.S., Celik, S., Gunay, E. et al. (2013), "Anti - cancer effects of thymoquinone, caffeic acid phenethyl ester and resveratrol on A549 non-small cell lung cancer cells exposed to benzo(a)pyrene", Asian Pacific Journal of Cancer Prevention, 14, 6159-64.

Woo, C.C., Loo, S.Y., Gee, V. et al. (2011), "Anti-cancer activity of thymoquinone in breast cancer cells: possible involvement of PPAR-gamma pathway", Biochemical Pharmacology, 82, 464-75.

Yin, Q.H., Yan, F.X., Zu, X.Y. et al. (2012), "Anti-proliferative and pro-apoptotic effect of carvacrol on human hepatocellular carcinoma cell line HepG-2", Cytotechnology, 64, 43-51. 